\title{
Emotions, Media and Politics.
}

Book by Karin Wahl-Jorgensen.

Polity Press, 2019, 220 pp.

Book Review by Dr. Walaa Fouda'.

1) Assistant Professor

College of Media and Mass Communication, The American University in the Emirates, UAE.

Karin Wahl-Jorgensen explores the complex relationship between emotions, media, and politics. The book includes analyses of the ways Facebook structures emotional reactions, the use of personal storytelling in feminist Twitter hashtags, and the communities created by political fandoms. It consists of seven chapters.

In her introductory Chapter One, "Taking Emotions Seriously," Wahl-Jorgensen focuses on the suspicion of emotions embedded within the fabric of Western liberal democracy, emphasizes the complex interplay of the range of distinctive positive and negative emotions, and, the ways these structure mediated politics. Wahl-Jorgensen suggests that we must engage with the concrete ways particular emotions encourage particular forms of public participation and expression, while discouraging others. 
In "Emotions Are Everywhere: The Strategic Ritual of Emotionality in Journalism," the author traces the movement of emotion through news media, and its consequences for political life. This Chapter Two reveals techniques of storytelling that Pulitzer Prize-winning authors have used, such as emotions and personal stories. According to the author, this craft requires "emotional intelligence." which involves an understanding of ways to craft stories that use emotional expression appropriately, yet also consistently elicit an emotional reaction in the audience.

The transitional Chapter Four concentrates on a range of different practices of personalized storytelling that operate as a political strategy which is explicit about its use of emotionality. In both conventional and emerging media forms, Chapter Four examines of the role of mediated anger in shaping mediated politics. The chapter opens by developing a typology of mediated anger, suggesting that we should view such anger from many perspectives: performative; discursively constructed; collective; and, political. To allow the reader better to understand how emotion is discursively constructed, the author presents a study of mainstream media coverage of anger in protest.

The author makes the most persuasive case for considering emotion as a factor in mediated politics in "Shifting Emotional Regimes: Donald Trump's Angry Populism." Chapter Five proposes that readers look at the role of anger as a mobilizing emotion in explaining the rise of Trump. It has demonstrated a shift in the "emotional regime" represented by media discourses following Trump's inauguration, comparing the shift from coverage of President Barack Obama's first swearing-in. The regime renders anger a viable framework for interpreting political life, and suggests that its performance is essential to the brand of populism represented by Trump. The author seeks to sketch out some of the complexities of expressions of anger.

The author warns in Chapter Six that the attention to the complex ways in which anger is constructed in mediated politics should not blind us to the role of positive emotions in mediated contexts. She also describes the complicated ways in which such emotions circulate in the hybrid media ecology.

She looks at what happens if citizens are driven by love. The author compared between Milifandom movement and Reddit in both communities engaged in fan practices by articulating their affective commitment to the object of their fandom.

Fans' discussions were shaped by ongoing political events and developments. Both communities were motivated by love, but for the Milifandom that uniformly associated with other positive forms of emotional expression, including desire and political interest. For the Reddit, their love of Trump served to mark their allegiance to a community that was in line with the tenets of angry populism the author discussed previously.

In the last chapter of the book, the author builds on the investigation of the relationship between platform design, affordances and emotional expression by tracing the political consequences of the emotional architecture of social media.

Because Facebook has become the most important social media platform, the history of this platform's reactions emoji highlight the commodification and marketization of public emotion, or what we might characterize as the emotional economy of our mediatized world. In the conclusion, the author refers to the relationship between emotions, media and politics is a dynamic relation. She closed the book with nine prepositions, which have conceptual, methodological, and epistemological dimensions. She emphasized on these prepositions should be seen as an invitation to future research.

Four of the prepositions encourage review:

First, emotions matter to mediated politics. Emotions could be seen as an 
epistemological "elephant in the room." That is, the massive unspoken presence that hovers over everything but that we have for so long refused to see, talk about or engage with. The book has sought to render the "elephant" visible by pointing to a variety of ways in which we can locate emotions in mediated politics.

Second, emotionality and rationality are not mutually exclusive. While Chapters Two and Three revealed that the best of storytelling draws in both "rational" information and emotional personalized storytelling, Chapter Six showed that political fan practices, such as the Milifandom combined emotional engagement with rationally based appeals to political engagement.

Third, love motivates us to engage in politics. If anger as negative emotion operates in complex ways in political life, Chapter 6 moved to the examination of complex positive emotions that of love.

Finally, multi-method approaches that combine the quantitative methods with the granularity and specificity of qualitative methods. And, with the emergence of online and social media platforms, any theory of media and politics must pay attention not only to how emotions are merely performed and constructed through the discourses of groups and individuals, but also are shaped by technological architectures and affordances.

This book represents a significant theoretical advance of the research on media and communication, particularly in light of major important political situations, such as the election of Donald Trump as president of the United States.

Drawing on a series of original studies, the book navigates the complex emotional landscape characterizing the relationship between emotions and politics; a relationship that long has been mediated and shaped by several media practices. Indeed, most important are the implications for the academy's media studies. Essential reading for scholars and students in this discipline, this important volume opens new ways of thinking about, and researching, the interactions among emotions, media, and politics. 
